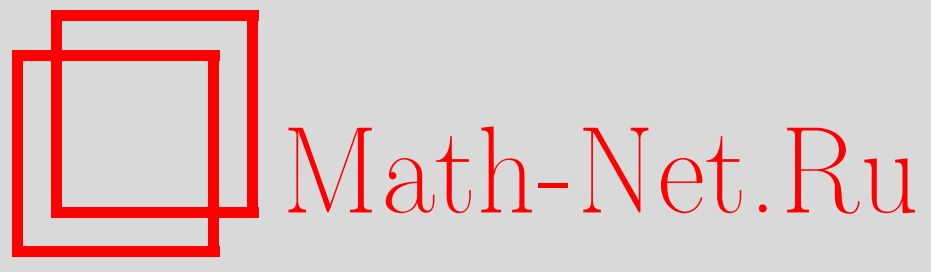

Международный математический конгресс, посвященный 300-летию со дня рождения Леонарда Эйлера, УМH, 2007, том 62, выпуск 1, 223

DOI: https://doi.org/10.4213/rm6422

Использование Общероссийского математического портала Math-Net.Ru подразумевает, что вы прочитали и согласны с пользовательским соглашением http://www . mathnet.ru/rus/agreement

Параметры загрузки:

IP : 3.89.197.203

26 апреля 2023 г., 08:03:57

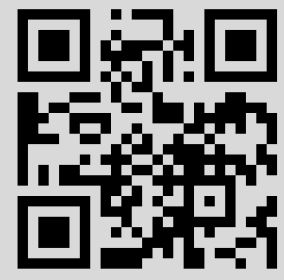




\section{Международный математический конгресс, посвященный 300-летию со дня рождения Леонарда Эйлера}

15 апреля 2007 года исполняется 300 лет со дня рождения выдающегося ученого Леонарда Эйлера, который жил и работал в Санкт-Петербурге с 1727 по 1741 и с 1766 по 1783 гг.

Согласно распоряжению Правительства Российской Федерации 300-летие со дня рождения Эйлера будет широко отмечаться в Санкт-Петербурге. Российская академия наук, Санкт-Петербургский Научный центр РАН, Санкт-Петербургское отделение Математического института им. В.А. Стеклова РАН, Международный математический институт им. Л. Эйлера, Санкт-Петербургский государственный университет, Санкт-Петербургское математическое общество и Фонд поддержки российской математики им. Леонарда Эйлера организуют Международный математический конгресс, посвященный этой дате. Конгресс будет проходить в течение июня-июля 2007 г. в Санкт-Петербургском отделении Математического института им. В. А. Стеклова РАН и в Международном математическом институте им. Л. Эйлера.

Организационный комитет конгресса: Л. Д. Фаддеев (председатель), Ю. Д. Бураго, А. М. Вершик, С. В. Востоков, В.А. Гриценко, П.Г. Зограф, И. А. Ибрагимов, С.В.Кисляков, Г. А. Леонов, Ю. В. Матиясевич, Г. А. Серегин, В. Н. Толстых, Э. А. Тропп.

Конгресс включает в себя Эйлеровский Фестиваль (10-12 июня) и серию конференций по различным областям математики, механики и физики, значительный вклад в развитие которых внес Леонард Эйлер.

Фестиваль (до 1000 участников) станет кульминацией научной программы празднования. В первый день Фестиваля состоится торжественное открытие: приветствие; пленарные доклады на тему “Эйлер и современная наука" по одному представителю от России и Германии: J. Brüning (Humboldt University, Berlin), академик В. В. Козлов (Математический институт им. В. А. Стеклова, Москва); вручение Золотой медали им. Л. Эйлера РАН, открытие бюста Л. Эйлеру, посещение могилы Л. Эйлера в Александро-Невской лавре, пресс-конференция, торжественный прием. На второй и третий дни запланированы научные пленарные доклады по приглашению. Предварительный список приглашенных докладчиков: A. Connes (College de France, IHES), F. Hirzebruch (Max-Planck-Institut für Mathematik, Bonn), L. Lovasz (Eotvos Lorand University, Budapest), В. Е. Захаров (Институт теоретической физики им. Л. Д. Ландау, Москва), Ю. И. Манин (Математический институт им. В. А. Стеклова, Москва; Max-Planck-Institut für Mathematik, Bonn), С. П. Новиков (Математический институт им. В. А. Стеклова; Институт теоретической физики им. Л. Д. Ландау, Москва), Л. Д. Фаддеев (Санкт-Петербургское отделение Математического института им. В. А. Стеклова).

Дополнительную информацию о конгрессе можно найти в Интернете на сайте http://www.pdmi.ras.ru/EIMI/2007/Euler300.

Адрес электронной почты конгресса: Euler300@imi.ras.ru.

Эйлеровский юбилей должен стать значительным событием в научной жизни России и всего мира. 